\title{
Odgovor autorica
}

\section{DANIJELA DOLENEC, DANIELA ŠIRINIĆ}

Fakultet političkih znanosti, Sveučilište u Zagrebu

Raspravu o egalitarnom sindromu koju je započela Dolenec (2014) smatramo vrijednom za domaće društvene znanosti jer ima za cilj kritiku i razvoj jedne od najutjecajnijih domaćih teorija. No, činjenicu da su autori (Štulhofer, Rimac i Vuković, u ovom broju) objavili osvrt koji ne mora proći proceduru recenzije, dok istovremeno insinuiraju da naš rad nije dovoljno dobar da bi prošao recenzentski postupak, odnosno da tog postupka možda nije ni bilo - ne smatramo korektnom. Time su osporili ne samo naš rad već i rad uredništva časopisa Politička misao i troje anonimnih recenzenata. Na čitateljima ostaje da prosude doprinose s obje strane, kao i da se u raspravu uključe kako bi je poveli u novim smjerovima. 